\title{
EXPLORING ETHNOMEDICINE PLANTS USED BY THE INDIGENOUS COMMUNITIES IN TERENGGANU, MALAYSIA: HUMAN HEALTH AND THE ENVIRONMENT
}

\author{
Muhammad Fuad Abdullah ${ }^{1,2}$, Elizabeth Pesiu ${ }^{3}$, Mohd Iqbal Mohd Noor ${ }^{1,2}$, Azniza Ahmad Zaini ${ }^{2}$, Amirah \\ Azzeri $^{4}$ and Mohd Tajuddin Abdullah ${ }^{5,6}$ \\ ${ }^{1}$ Faculty of Business and Management, Universiti Teknologi MARA Raub Campus, 27600 Raub, Pahang, \\ Malaysia. \\ ${ }^{2}$ Institute for Biodiversity and Sustainable Development, Universiti Teknologi MARA, 40450 Shah Alam, \\ Selangor. \\ ${ }^{3}$ Faculty of Science and Marine Environment, Universiti Malaysia Terengganu, 21030 Kuala Nerus, \\ Malaysia. \\ ${ }^{4}$ Public Health Unit, Department of Primary Health Care, Faculty of Medicine and Health Sciences, \\ Universiti Sains Islam Malaysia, Nilai, Negeri Sembilan. \\ ${ }^{5}$ Faculty of Fisheries and Food Science, Universiti Malaysia Terengganu, 21030 Kuala Nerus, Terengganu, \\ Malaysia. \\ ${ }^{6}$ Academy of Sciences Malaysia, 20th Floor, West Wing Menara Matrade, 50450 Kuala Lumpur, Malaysia.
}

Corresponding author: Mohd lqbal Mohd Noor

Email: mohdiabalmn@uitm.edu.my

\section{ABSTRACT}

Indigenous community in Malaysia practices traditional medicine, particularly from the surrounding plants to cure different diseases and illnesses. This traditional way of life has been practised for centuries and passed down through generations. This study aims to document medicinal plants that have been used by the Orang Asli to treat illness. A qualitative ethnomedical study was done to document the species that were believed to have medicinal value. This study was carried at all three resettlement villages in Terengganu. Eleven informants who were the head of household with the age of over 30 years old were interviewed. Fieldwork surveys, observation and face-to-face communication were methods used in this study. The finding shows that most of the Orang Asli community in Terengganu are still dependent on plants and herbs to cure ailments. A total of 106 species that belong to 55 plant families were used by them. This study will encourage researchers in various fields such as ethnobotanical, ethnozoological, ethnomedicinal and pharmaceutical and toxicological accomplishment of flora and fauna from these areas. As such, these medicinal plants need some more extensive efforts to validate scientifically and clinically were to prove the ethnomedical claims toward them.

Keywords: Indigenous community, ethnomedicine, traditional knowledge, plants, Terengganu

\section{INTRODUCTION}

Herb plants can be defined as small, non-woody shrub, which their leaves can be turned into food, medicine, and fragrance. Herbal medicine is the treatment of diseases that use medicinal plants internally and externally to restore the health of the patient. The medical system associated with the use of nutritious plants has improved the ability of patients to recover and currently being strengthened by scientific advances $^{1}$. In Malaysia, this source of traditional medicines is available from all parts of the plant. There are at least 1,158 species of tall plants in Malaysia recorded as having a medical value where 1,075 of them are flowering plants, 75 species of ferns and seven species of gymnosperm families ${ }^{2}$. As the evidence of traditional and complementary medicine, particularly the herbal plants become apparent, the Ministry of Health Malaysia has established a Traditional and Complementary Medicine (TCM) division to enhance quality research on this area and to monitor the use of such TCM therapies so that they are of high quality and safe to be used.

The World Health Organization ${ }^{3}$ shows that folk medicinal practices all-inclusive with Chinese, Ayurveda by Indian and Greek as well as various forms of traditional medicine. Besides, it commonly refers to complementary and alternative medicine by using various natural resources. This folk knowledge tradition has been widely reported since the British colonial. According to Nordin Lajis ${ }^{4}$, a viable plant is a plant that contains a compound that modifies the physiology of mammal and has been used by humans for this purpose. It is estimated there are nearly 250,000 of these medical plant species where about $60 \%$ can be found in the tropical forest.

Plants have multi different functions and use where it providing food, shelter, drugs, timber, wood as well as kitchen fuel especially for vulnerable residents in developing counties. 
Besides, it plays a vital role in preserving the ecosystems, maintaining and preserving ecological balance by stabilized the ecosystem. Deniably, plants have been used as traditional medical remedies for centuries ${ }^{5}$. These remedies commonly found within the residencies. However, this ethnomedicinal practice has never been well documented as it is inherited by elders through generation through verbal and hands-on activities. According to Alan ${ }^{6}$, almost $80 \%$ of the worldwide community using traditional medicine as an alternative to cure ailments. Thus, it became second and alternative after sophisticated treatment which well used by native people.

The study of tribal knowledge regarding plants is significant toward ethnomedical research. To date, there is adequate literature of ethnomedical understanding of Orang Asli in Terengganu, though there are some reported on other regions in Malaysia ${ }^{7,8}$. Besides, it faces terrible threats such as ecological globalization and cultural homogenization. Thus, aggressive action has to be done before this precious heritage knowledge lost for good. Therefore, this study attempt to document the traditional medicinal plants that have been used by the Orang Asli in Terengganu. It helps the Orang Asli to conserve their traditional knowledge and practices of medicinal plants as well as natural resources that might be useful for the future generation. The finding of this study will give a big impact on further herbs clinical research due to virtuous health values.

\section{METHODS}

\section{Sampling}

This is exploratory research carried out at three Orang Asli resettlement villages in different

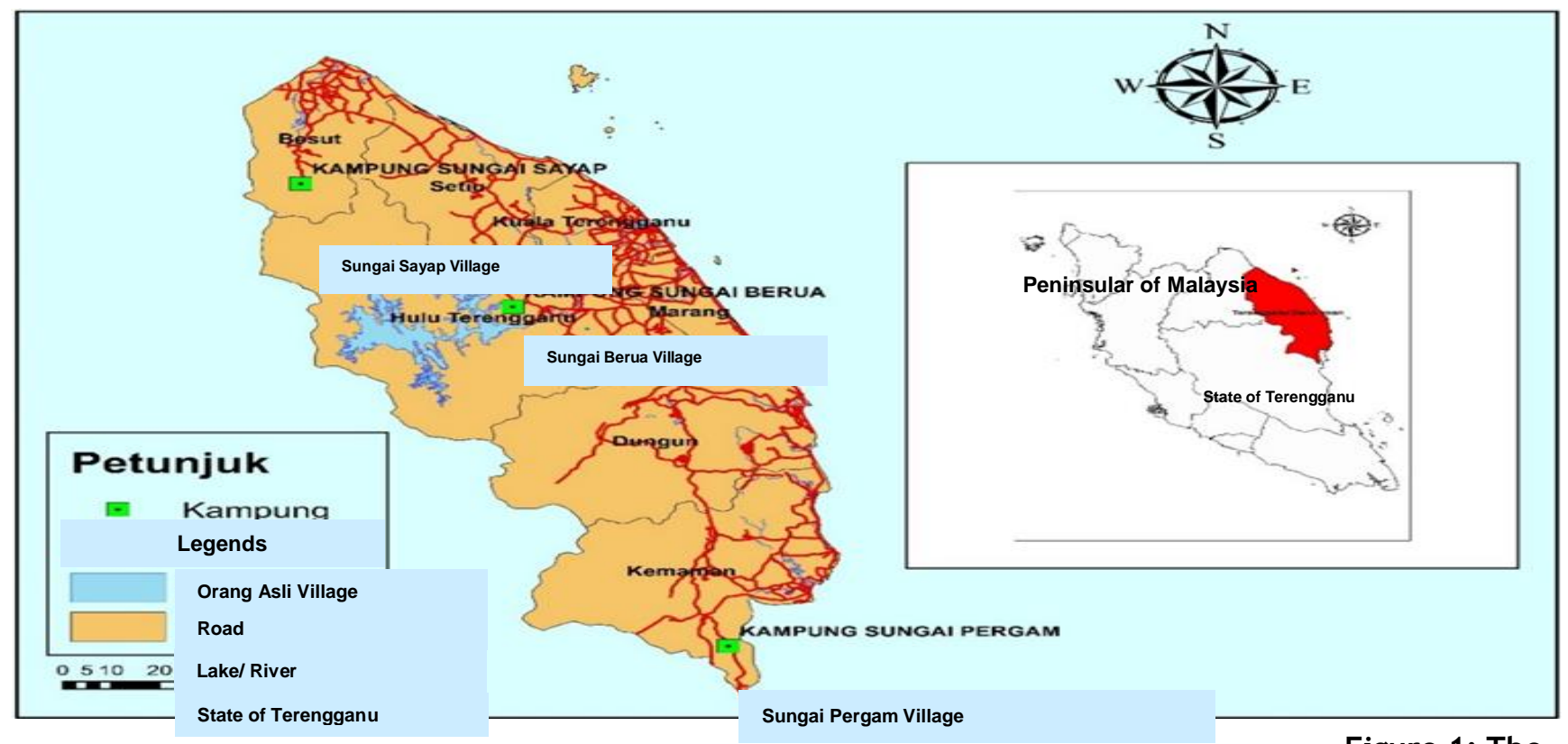

location of Orang Asli villages (Source: Abdullah et al. ${ }^{9}$.)

Figure 1: The

districts of Terengganu, Malaysia (East Coast of Peninsular Malaysia). The exact location of the study site showed in Figure 1. This study was carried out among the Semaq Beri and Bateq tribes in Sungai Berua village, Hulu Terengganu $\left(5^{\circ} 04^{\prime} 08.5^{\prime \prime} N 102^{\circ} 52^{\prime} 19.2^{\prime \prime} \mathrm{E}\right)$; Sungai Pergam village, Kemaman $\left(4.0471^{\circ} \mathrm{N} 103.2859^{\circ} \mathrm{E}\right)$; and Sungai Sayap village, Besut $\left(5^{\circ} 2722.4^{\prime \prime} \mathrm{N} 102^{\circ}\right.$ 31'17.3 E).

\section{Data Collection}

The interviews began with a brief introduction of the researcher team. The purpose was to gain trust and build a good relationship between the researcher and villagers especially the elderly. Thus, they give the information freely and openly as outlined without any barrier. The Focus Group Discussion (FGD) approach was used to gain brief information about their traditional knowledge, surrounding natural environment and identified key informants. Then, the informant was selected as required by purposive sampling technique and interview procedure. Besides that, the snowball approach has also been used during the preliminary study to gather more information from the informants. The sampling technique requires, one informant, suggested the others to become the informant whom he or she believed the next person could give the information regarding the traditional knowledge by using natural resources. The informants gave the information needed verbally and through fieldworks study. Most of the plant's samples were handpicked through direct and participant observation. Furthermore, to assure and reliability of data the informants should be the head of household with the age must be over 30 years old as they are experienced and knowledgeable. They were questioned individually by a set of semi-structured interview 
with the assistance of the Department of Orang Asli Affair's officer and the headman (Tok Batin). Besides, it is easier for the researcher to get clear information and verify the fact instantly with the existence of local authorities because some of the informants used Orang Asli language

\section{RESULTS}

This study applied qualitative research approach by in-depth interviews and participant observations during fieldworks. Through this method, 11 informants were interviewed. Recent study by Abdullah et al. ${ }^{9}$, distribution population of the villages were 1326 with 182 head of and their accent to give the information needed besides the Malay language where it is used as an intermediate language. The collected data were analysed by cross-checking and referring to the Malaysia Biodiversity Information System (MyBIS) for an accurate plants list.

Table 1: Distribution of Orang Asli in Terengganu

\begin{tabular}{lllll}
\hline District & Village & $\begin{array}{l}\text { Orang } \\
\text { Sub-tribe }\end{array}$ & $\begin{array}{l}\text { Asli } \\
(\mathrm{HoH})\end{array}$ & Poad Household \\
\hline Kemaman & Sungai Pergam & Semaq Beri & 8 & 683
\end{tabular}

$\begin{array}{llll}\text { Hulu Terengganu } & \text { Sungai Berua } & \text { Semaq Beri } & 95\end{array}$

household as presented in Table 1. Based on the data collections conducted, 130 medicinal plants species that belonging to 62 families used by the Orang Asli of Terengganu were identified and all the plants were presented in Table 2 .
Hulu Terengganu

Besut
Sungai Sayap Bateq
140
605

Total

\section{DISCUSSION}

The relationship between traditional knowledge and medicinal plants can be seen through indigenous people's livelihood who extensively applied traditional medicine potion to cure various ailments that occurred among their tribes. Malaysia is a multi-racial country where the indigenous people have only contributed a small portion of the Malaysian total population ${ }^{10}$. The indigenous people in Malaysia are called 'Orang Asli'. They are also known as the first people who are considered the native community of Malaysia. According to Lee et al. ${ }^{11}$., Malaysia consists of 90 different groups of indigenous tribes. Nevertheless, the Orang Asli community can only be found in the Peninsular of Malaysia while the others live in Borneo Island. The Orang Asli tribes are distinguished by their geographical, language, and morphological characteristics. In Malaysia, there are three major tribes recognised as Negrito, Senoi and Proto-Malay. Each of these tribes is divided into three other sub-tribes 9 . According to Abdullah et al. ${ }^{12}$, Malaysia lives by more than 178,000 Orang Asli community whereby $60 \%$ of them are still live deep in the rain forests. This marginalized tribe has a unique cultural heritage, belief and socioeconomic compared to other mainstream races $^{13}$. According to Ong et al. ${ }^{7,8}$, the Orang Asli community depends on surrounding natural resources for their survival as practised by ancestors before. Despite embraced by ancient culture and beliefs, the Orang Asli community rely on natural resources especially plant for medicinal purpose. They still depend on phytomedicines in traditional medicinal plant's remedies due to easy availability around the nearby forest, difficult access to modern treatment (clinic) due to remote residencies location, cultural acceptability and poor socioeconomic conditions.

The tropical rainforest in Malaysia has about six to seven thousand species of plants that have been widely used as medicinal plants by Orang $\mathrm{Asli}^{14}$. Some of them are multi-purpose to cure ailments where each part of the plant has its function with different methods of use. Most plants grow naturally wild in the forest nearby Orang Asli village. Thus, they were easily recognized by the informants during the fieldwork. Most of the species are taken internally by eating raw or paste form. Besides, several of the species are commonly consumed and have been commercialized among other races in Malaysia such as Goniothalamus macrophyllus (tongkat ali) and Labisia pumila (kacip fatimah). Based on this study, the plants that commonly used by the Orang Asli were belonged to rubiaceae (Eight species), zingiberaceae (Seven species) and vitaceae (Five species). The life of a plant-based society is surely discovering many of its surrounding plants for medicine. Their values and knowledge need to be developed and maintained to continue to 
be passed on to future generations. Plants are an essential element of human life and have been used for generations in many uses. This is further explained by Ong et al. ${ }^{7,8}$, who also described the history of herbal medicine that has been used to treat diseases since the beginning of human civilization that began in China. From the historical record of other civilized nations, there is also knowledge of plants that have nutrients. Greeks and Romans like Hippocrates were also recognized as pioneering herbal medicine and Hippocrates was recognized as the Father of Medicine. While contributions by Dioscorides and Theophrastus expand the field of herbal medicine.

Orang Asli's is surrounded by nature and its resources ${ }^{15}$ which allows them to use it in their daily routine especially for food and medicine ${ }^{16}$. The use of natural resources like herb plants not only exposes knowledge of the health tradition but also explores its scientific understanding and connection to the cultural and historical background of Orang Asli themselves. Orang Asli is among the hundreds of people who have used the plants in the forest as medicines to cure diseases ${ }^{17}$. The practice passed down through the generations allowed them to discover and understand the secrets of plants that could be used as herbs to cure diseases until each species was identified for their use. Orang Asli commonly uses herbs to prevent, cure and protect against diseases such as fever, diarrhoea, haemorrhoids, cancer as well as strengthening the body's immune system ${ }^{18}$. It is also consumed for health care such as nourishing young and post-natal care. Besides, it used in the ritual ceremony. Although, Orang Asli never receives any formal education they specialize in most species of wild plants. They also ensure the ecological systems of herbs continue to remain in the forests for the benefit of their generation such as maintaining practices and rituals while harvesting forest products $^{19}$. They believe that some plants can cure wound and cut, relieve physical pain, boosting inner energy and blood circulation. It is no surprise that the Orang Asli is a community that is rich in knowledge and wisdom for its management of nature. The result of the wisdom of traditional knowledge passed down from previous generations is applied to their lives. This process exposes the existence of a system of informal education and its unique science. Further, it gives meaning to the philosophy of life of the Orang Asli people themselves as manifested in the form of customary systems, religions and beliefs, cosmology, prohibitions and so on that govern the way they act and interact with other people and nature ${ }^{20}$.

Generally, the practice of Orang Asli folk medicine has two main aspects namely spells and the use of various types of plants. Orang Asli who lives remotely in the forest rely heavily on materials, plants in the wild. Only a few of them use the edge plant. Mustaffa Omar and Zanisah Man ${ }^{21}$, have documented nearly 100 Orang Asli medicinal plants from the Jakun, Semelai and Bateq communities that are used to treat various diseases. Most of their research is regarding plants for the treatment of women after childbirth, skin diseases, bleeding, colds fever, toothache, stomach aches, children's baths, eye pain, vein, pain, hypertension and improving inner strength and family planning practices. Orang Asli is well-known for its privilege and ability to identify plants that can serve as a cure for many diseases. However, herbs that are extremely rich in nutrients can be used as an alternative to modern medicine as it needs a strict process to be followed to store their nutrients.

Orang Asli's traditional knowledge plays a significant role in the community. Although it does not have any definite definition, traditional knowledge can be described as knowledge, know-how, skill and practices that are developed, sustained and transmitted by oral and discipleship practices through generation within a community, often forming part of its cultural or spiritual identity 22 . Such knowledge, education and philosophy were passed down directly and indirectly by teachers and herbalists from generation to generation, thus shaping its heterogeneous social practices to enhance the unique cultural values that Malaysia has. Thus, traditional knowledge among Orang Asli is important for the formulation of plant medicine to get the exact prescriptions to cure specific ailments. Furthermore, traditional knowledge does not contribute to any forest damages or species extinction as the Orang Asli only takes nothing more than the plants that used for their remedies ${ }^{23}$. Nevertheless, this precious heritage seems not to be applied to buy the younger generation recently. They choose not to believe this folk knowledge due to doubtful efficiency as well as surrounding social development. Furthermore, it is competitively used by advanced synthetic medicines which are scientifically proven. Hence, this unwritten tribal knowledge becomes no more important than before ${ }^{24}$.

For decades, Orang Asli commonly lives by hunter and gatherer activity as a way of their lifestyle ${ }^{25}$.It is about utilizing natural resources for survival by various conventional socioeconomic activities such as hunting, fishing, building, handicraft and also curing simple ailments. It gives a crystal picture of how close the Orang Asli community with the natural environment ${ }^{26}$. Therefore, environmental ecological changes (modernization and land development) give a big impact on their sustainable livelihood and symbiotic bond with nature. Mainstream development nowadays has made rapid changes toward the natural environment by boost up economic, political and 
cultural changes. Some of the traditional knowledge was diminished from Orang Asli culture. The Orang Asli traditional knowledge or sometimes interchangeable with traditional ecological and environmental knowledge is arguably one of the most important aspects that distinguish Orang Asli management systems from the domain of Western 'scientific' resource management models. The livelihoods of rural households depend on the accessibility of natural resources such as agriculture, livestock, poultry, fisheries and forest as well as the underlying environmental services that sustain these resources ${ }^{27}$.

To date, the Orang Asli community are still relying on these practices to cure ailments especially for those who live deep in the forest which is far from road access for modern health facilities. This survival ethno-health care has been practised a long time ago among the community and being able to cure their ailments. Thus, herbs and plants used by the Orang Asli are ethno-medically proven. However, those species need to be well documented for clinical test and before they are lost for good due to mess development.

\section{CONCLUSION}

Plants are natural drugs where it helping people especially the native community to boost up their health care and livelihood in the traditional way. Normally, it occurred among the tribal who live in remote areas where they have hardly access to modern health care facilities. This ethnomedical study shows that the Orang Asli in Terengganu is still relying on plants and herbs to cure ailments that occurred in their community. They consume 62 families with 130 plants and herbs species for health care purpose. Most of the species can be found easily in the nearby forest. Nevertheless, traditional medicinal plants are not an option anymore. They prefer to have synthetic medicine and going to a nearby clinic for medical treatment. Narratively, the wellorganized resettlement that builds by the government which completed with all the basic infrastructures and amenities to uplift their socio status have turned down their ancestral heritage and belief. Furthermore, the death ratio among their people affected by diseases has turned their mind toward modern treatments. Therefore, this traditional knowledge where it put plants as primary remedies to cure ailments become no longer the priority for Orang Asli, especially in the younger generation.

All of the species may have the potential to be test clinically as they been used traditionally by the Orang Asli. These potential natural resources will give new hope for the pharmaceutical industry in creating new drugs for health products and supplements in the mainstream. Yet, it must be consumed in a right prescribe and by the advice of the professionals. To ensure this traditional knowledge regarding plants and herbs getting far from extinction, well documentation of plants list used by the vulnerable community has to be closely discovered. It will be useful for the next generations to know the species and methods that have been used by folk generations to cure ailments.

\section{Conflict of interest}

The authors declare no potential conflict of interest.

\section{Acknowledgements}

This study was funded by the Ministry of Higher Education Malaysia through Transdisciplinary Research Grant Scheme (TRGS vote no. 59373) awarded to Professor Dato' Dr. Mohd Tajuddin Abdullah. The authors gratefully acknowledge the Institute of Tropical Biodiversity and Sustainable Development, Universiti Malaysia Terengganu for accommodates the services and facilities. Deep appreciation for the permission and cooperation of the village authorities and Department of Orang Asli Affairs.

\section{REFERENCES}

1. Klaus Schwab. The Fourth Industrial Revolution. World Economic Forum. 2016.

2. Topol EJ. High-Performance Medicine: The Convergence of Human and Artificial Intelligence. Nature medicine. 2019;25(1): 44-56. doi: https://doi.org/10.1038/s41591-0180300-7

3. Hamet $P$, Tremblay J. Artificial intelligence in medicine. Metabolism. 2017 Apr 1;69:S36-40. doi: https://doi.org/10.1016/j.metabol.2017. 01.011

4. Theofilatos K, Pavlopoulou N, Papasavvas $C$, et al. Predicting protein complexes from weighted protein-protein interaction graphs with a novel unsupervised methodology: evolutionary enhanced Markov clustering. Artificial intelligence in medicine. 2015 Mar 1;63(3):181-9. doi: https://doi.org/10.1016/j.artmed.2014. 12.012

5. Krittanawong $\mathrm{C}$, Zhang $\mathrm{H}$, Wang $\mathrm{Z}$, Aydar M, Kitai T. Artificial intelligence in precision cardiovascular medicine. Journal of the American College of Cardiology. 2017 May 22;69(21):2657-64. doi: https://doi.org/10.1016/j.jacc.2017.03. 571 
6. Krittanawong $\mathrm{C}$. The rise of artificial intelligence and the uncertain future for physicians. European journal of internal medicine. 2018; 48: e13-e14. doi: https://doi.org/10.1016/j.ejim.2017.06. 017

7. Cornet G. Robot companions and ethics: A pragmatic approach of ethical design. Journal international de bioéthique. 2013;24(4):49-58. doi: https://doi.org/10.3917/jib.243.0049

8. Health Ministry Plans to Use Artificial Intelligence. The Star. March 13, 2019. https: / /www.thestar.com.my/news/nati on/2019/03/13/health-ministry-plans-touse-artificialintelligence\#CR3iDwxx1R0gLbtp.99. Accessed November 29, 2019.

9. Kamal B. A.I. can help improve patient outcomes. New Strait Times. November 17 , 2018. https://www.nst.com.my/opinion/colum nists/2018/11/432065/ai-can-helpimprove-patient-outcomes. Accessed November 28, 2019.

10. Sullivan T. Half of hospitals to adopt artificial intelligence within 5 years. Healthcare IT News. April 11, 2017. https://www.healthcareitnews.com/new s/half-hospitals-adopt-artificial-

intelligence-within-5-years. Accessed on November 28, 2019.

11. Clark $\mathrm{H}$. The roadmap to introducing Al and robotics in healthcare. Forbes Middle East. April 18, 2018. https: / /www.forbesmiddleeast.com/feat ured/special-editions/the-roadmap-tointroducing-ai-and-robotics-inhealthcare. Accessed on November 28, 2019.

12. Chui M, Bughin J, Hazan E, et al. Artificial intelligence the next digital frontier? McKinsey Global Institute; 2017.

13. Oh S, Kim JH, Choi SW, et al. Physician Confidence in Artificial Intelligence: An Online Mobile Survey. Journal of medical Internet research. 2019; 21(3): e12422. doi: https://doi.org/10.2196/12422.

14. Birkett MA, Day SJ. Internal Pilot Studies for Estimating Sample Size. Statistics in medicine. 1994; 13(23-24): 2455-2463. doi:

https: / / doi.org/10.1002/sim.4780132309

15. Taber KS. The Use of Cronbach's Alpha When Developing and Reporting Research
Instruments in Science Education. Research in Science Education. 2018; 48(6): 1273-1296. doi: https: / / doi.org/10.1007/s11165-0169602-2

16. Future Health Index. 2019. Transforming Healthcare Experiences - Exploring the Impact of Digital Health Technology on Healthcare Professionals and Patients. http://www.indiaenvironmentportal.org. in/files/file/Future_Health_Index_2019.p df. Accessed on November 28, 2019].

17. Miller DD, Brown EW. Artificial Intelligence in Medical Practice: The Question to the Answer? Am J Med. 2018;Feb;131(2):129-133. doi: 10.1016/j.amjmed.2017.10.035.

18. World Health Organization. 2018. Global Health Ethics - Big Data and Artificial Intelligence.

https://www.who.int/ethics/topics/bigdata-artificial-intelligence/en/ Accessed on November 28, 2019.

19. Okonji PE. Use of computer assistive technologies by older people with sight impairment: Perceived state of access and considerations for adoption. British Journal of Visual Impairment. 2018;May;36(2):128-42. doi: https: / / doi.org/10.1177/0264619617752 760

20. Enwald $H$, Kangas $M$, Keränen $N$, Korpelainen R, Huvila I, Jämsä T. Opinions and use of mobile information technology among older people in northern finland-preliminary results of a population based study. Proceedings of the Association for Information Science and Technology. 2016;53(1):1-5. doi: https://doi.org/10.1002/pra2.2016.1450 5301119

21. Schreder G, Smuc M, Siebenhandl K, Mayr $E$. Age and Computer Self-Efficacy in the Use of Digital Technologies: An Investigation of Prototypes for Public Self-Service Terminals. Proceedings of the Universal Access in Human-Computer Interaction. User and Context Diversity, LNCS. 2018; Volume 8010, pages 221230. Springer Berlin Heidelberg, Germany.

22. Deiner MS, Lietman TM, Porco TC. Uncertainties in Big Data When Using Internet Surveillance Tools and Social Media for Determining Patterns in Disease Incidence-Reply. JAMA ophthalmology. 2017 Apr 1;135(4):402-3. doi: 10.1001/jamaophthalmol.2017.0140 
23. Benke KK. Uncertainties in big data when using Internet surveillance tools and social media for determining patterns in disease incidence. JAMA ophthalmology. 2017 Apr 1;135(4):402.doi: doi:10.1001/jamaophthalmol.2017.0138

24. Gulshan V, Peng $L$, Coram $M$, et al. Development and Validation of a Deep Learning Algorithm for Detection of Diabetic Retinopathy in Retinal Fundus Photographs. JAMA. 2016;316(22):24022410. doi:10.1001/jama.2016.17216

25. Kermany DS, Goldbaum M, Cai W, et al. Identifying medical diagnoses and treatable diseases by image-based deep learning. Cell. 2018 Feb 22;172(5):112231.

doi: https://doi.org/10.1016/j.cell.2018.02.0 10

26. Esteva A, Kuprel B, Novoa RA, Ko J, Swetter SM, Blau HM, Thrun S. Dermatologist-level classification of skin cancer with deep neural networks. Nature. 2017 Feb;542(7639):115-8. doi: https://doi.org/10.1038/nature21056

27. Cheng JZ, Ni D, Chou YH, Qin J, Tiu CM, Chang YC, Huang CS, Shen D, Chen CM. Computer-aided diagnosis with deep learning architecture: applications to breast lesions in US images and pulmonary nodules in CT scans. Scientific reports. $2016 \mathrm{Apr}$ 15;6(1):1-3.doi: https://doi.org/10.1038/srep24454

28. Doraiswamy PM, Blease C, Bodner K. Artificial intelligence and the future of psychiatry: Insights from a global physician survey. Artificial Intelligence in Medicine. 2020 Jan 1;102:101753.3. doi:

https://doi.org/10.1016/j.artmed.2019. 101753

29. Kelly CJ, Karthikesalingam A, Suleyman $M$, Corrado G, King D. Key challenges for delivering clinical impact with artificial intelligence. BMC Medicine. 2019 17:195. doi: https://doi.org/10.1186/s12916-
$019-1426-2$

30. Liang $\mathrm{H}$, Tsui BY, Ni H, Valentim CC, Baxter SL, Liu G, Cai W, Kermany DS, Sun $X$, Chen J, He L. Evaluation and accurate diagnoses of pediatric diseases using artificial intelligence. Nature medicine. 2019 Mar;25(3):433-8. doi: https://doi.org/10.1038/s41591-0180335-9

31. Rajkomar A, Oren E, Chen K, Dai AM, Hajaj N, Hardt $M$, et al. Scalable and accurate deep learning with electronic health records. NPJ Digit Med. 2018; $1: 18$. doi: https://doi.org/10.1038/s41746-0180029-1.

32. Stephen Hawking. Artificial intelligence could be the greatest disaster in human history. Independent. October 2016. https://www.independent.co.uk/news/p eople/stephen-hawking-artificialintelligence-diaster-human-historyleverhulme-centre-cambridgea7371106.html. Accessed November 28, 2019. 
Table 2: Plants used by the Orang Asli in Terengganu, Malaysia

\begin{tabular}{|c|c|c|c|c|c|}
\hline Family & Scientific name & *Native Name & Part Used & Ailment Treated & Method \\
\hline \multirow[t]{11}{*}{ Acanthaceae } & \multirow{4}{*}{$\begin{array}{l}\text { Andrographis paniculata (Burm. } \\
\text { F.) Wall. Ex Nees }\end{array}$} & \multirow[t]{4}{*}{ Hempedu Bumi } & \multirow[t]{4}{*}{ Whole plants } & Hypertension, fever & Infusion taken orally. \\
\hline & & & & Diabetes & $\begin{array}{l}\text { Decoction with Orthosiphon aristatus taken } \\
\text { orally. }\end{array}$ \\
\hline & & & & Influenza, chest pain, tonsillitis & Decoction taken orally. \\
\hline & & & & Bites, stings & Poultice applied topically and taken orally. \\
\hline & \multirow[t]{3}{*}{ Asystasia coromandeliana Nees } & \multirow[t]{3}{*}{ Rumput Israel } & \multirow[t]{3}{*}{ Leaves } & Constipation & Leave decoction taken orally. \\
\hline & & & & Swellings, cuts, wounds & Poultice applied topically. \\
\hline & & & & Muscle cramps & Poultice with garlic-applied topically. \\
\hline & \multirow[t]{4}{*}{ Justicia gendarussa Burm. $\mathrm{f}$. } & \multirow[t]{4}{*}{ Gandarusa hitam } & \multirow[t]{2}{*}{ Leaves } & Flatulence & Pounded with lime fruit, applied topically. \\
\hline & & & & Post-partum, coughs, thrush & Heated and applied on abdomen. \\
\hline & & & \multirow[t]{2}{*}{ Roots } & Coughs & Decoction taken orally. \\
\hline & & & & Thrush & Decoction applied topically. \\
\hline \multirow[t]{6}{*}{ Amaryllidaceae } & \multirow[t]{3}{*}{ Allium cepa L. } & \multirow[t]{3}{*}{ Bawang merah } & \multirow[t]{3}{*}{ Bulbs } & Fever, flatulence, & Paste mixed with oil applied topically. \\
\hline & & & & Cuts, sores, pimples, abscess & Poultice applied topically. \\
\hline & & & & $\begin{array}{l}\text { Diarrheal, coughs, influenza, } \\
\text { aches }\end{array}$ & Blended and taken orally. \\
\hline & \multirow[t]{3}{*}{ Allium sativum $\mathrm{L}$. } & \multirow[t]{3}{*}{ Bawang putih } & \multirow[t]{3}{*}{ Bulbs } & Flatulence & Paste mixed with oil applied on abdomen. \\
\hline & & & & Stings, bites, cuts & Poultice or juice applied topically. \\
\hline & & & & Coughs, asthma, abdomen pain & Juice mixed with honey taken orally. \\
\hline Anacardiaceae & Spondias dulcis & Kedondong & Fruit & Tissue recovery and vitamin & Eat it raw or cook. \\
\hline \multirow[t]{10}{*}{ Annonaceae } & \multirow[t]{7}{*}{ Annona muricata L. } & \multirow[t]{7}{*}{ Durian belanda } & \multirow[t]{4}{*}{ Leaves } & Head lice & Pounded leaves with water applied topically. \\
\hline & & & & Nightmares & Leaves placed under pillows. \\
\hline & & & & Sore throat & Infusion of dry leaves taken orally. \\
\hline & & & & Back pain, joint aches & Decoction taken orally. \\
\hline & & & Barks & Infertility for male and female & Decoction taken orally. \\
\hline & & & Fruits & $\begin{array}{l}\text { Post-partum, } \\
\text { hypertension }\end{array}$ & Fruit juice taken orally. \\
\hline & & & Seeds & Intestinal parasites & $\begin{array}{l}\text { Decoction or infusion of powdered seeds taken } \\
\text { orally. }\end{array}$ \\
\hline & Goniothalamus macrophyllus & Tongkat ali & Roots & $\begin{array}{l}\text { Aches, pains, low sexual energy, } \\
\text { hypertension }\end{array}$ & Decoction taken orally. \\
\hline & Polyalthia bullata King & Tongkat ali batu & Roots & $\begin{array}{l}\text { Inner energy for men, } \\
\text { indigestion, strengthens immune } \\
\text { system }\end{array}$ & Decoction taken orally. \\
\hline & Goniothalamus macrophyllus & Gajah beranak & Root & Fever and post-partum & Decoction and taken orally. \\
\hline
\end{tabular}




\begin{tabular}{|c|c|c|c|c|c|}
\hline \multirow{4}{*}{ Apiaceae } & \multirow[t]{4}{*}{ Centella asiatica (L.) Urban } & \multirow[t]{4}{*}{ Pegaga } & \multirow[t]{2}{*}{ Leaves } & Aging & \multirow{4}{*}{$\begin{array}{l}\text { Juice taken orally. } \\
\text { Poultice applied topically. } \\
\text { Decoction with salt added applied topically. } \\
\text { Decoction taken orally. }\end{array}$} \\
\hline & & & & Cuts, sores, skin diseases & \\
\hline & & & \multirow[t]{2}{*}{ Whole plants } & Leucorrhoea & \\
\hline & & & & $\begin{array}{l}\text { Post-partum, headache, } \\
\text { hypertension, lip cracks }\end{array}$ & \\
\hline \multirow[t]{2}{*}{ Apocynaceae } & \multirow[t]{2}{*}{ Catharanthus roseus (L.) G. Don } & \multirow[t]{2}{*}{ Kemunting China } & Roots & Abortion and menstrual & Decoction taken orally. \\
\hline & & & Barks & $\begin{array}{l}\text { Malaria, diabetes, chancres and } \\
\text { hypertension }\end{array}$ & Decoction taken orally. \\
\hline \multirow[t]{2}{*}{ Arecaceae } & \multirow{2}{*}{$\begin{array}{l}\text { Areca catechu L. } \\
\text { Iguanura sp. }\end{array}$} & Pinang & Fruits & Fever & Soaked in water incantation and taken orally. \\
\hline & & Pokok kura-kura & Leaves & Malaria & Decoction taken orally. \\
\hline \multirow[t]{2}{*}{ Aristolochiaceae } & \multirow{2}{*}{$\begin{array}{l}\text { Thottea grandiflora Rottb. } \\
\text { Thottea grandiflora Rottb. }\end{array}$} & Perdu beruang & Roots & Asthma & Decoction taken orally. \\
\hline & & Hempedu beruang & Roots & Cough & Decoction taken orally. \\
\hline \multirow[t]{2}{*}{ Asparagaceae } & \multirow{2}{*}{$\begin{array}{l}\text { Peliosanthes lurida Ridl. } \\
\text { Peliosanthes violacea Wall }\end{array}$} & Lemba seratus & Roots & Flatulence & Decoction taken orally. \\
\hline & & Rambu suntum & Roots & Veins aches & Decoction taken orally. \\
\hline \multirow[t]{8}{*}{ Asteraceae } & \multirow{3}{*}{$\begin{array}{l}\text { Chromolaena odorata (L.) R.M. } \\
\text { King \& H. Rob. } \\
\text { Gynura procumbens (Lour.) } \\
\text { Merr. } \\
\text { Ageratum conyzoides L. }\end{array}$} & \multirow{3}{*}{$\begin{array}{l}\text { Kapal terbang } \\
\text { Bayam cina } \\
\text { Rumput pareh jarang/ } \\
\text { rumput sekodok }\end{array}$} & Leaves & Cuts, wounds & Pounded and applied topically. \\
\hline & & & Roots & Fever & Decoction taken orally. \\
\hline & & & Leaves & $\begin{array}{l}\text { trachoma, cut, stomach ache and } \\
\text { cough }\end{array}$ & Poultice applied topically. \\
\hline & \multirow[t]{3}{*}{ Pluchea indica (L.) Less. } & \multirow[t]{3}{*}{ Beluntas } & Roots & Fever & Decoction taken orally. \\
\hline & & & Leaves & $\begin{array}{l}\text { Fever, heuropathy, menstrual, } \\
\text { odor }\end{array}$ & Poultice applied topically. \\
\hline & & & Seeds & Haematuria & Decoction taken orally. \\
\hline & \multirow[t]{2}{*}{ Blumea balsamifera (L.) DC. } & \multirow[t]{2}{*}{ Sembung } & Roots & $\begin{array}{l}\text { Stomach ache, anorexia, malaria } \\
\text { and fever }\end{array}$ & Decoction taken orally. \\
\hline & & & Leaves & $\begin{array}{l}\text { Stomach ache, anorexia, } \\
\text { menstrual, rheumatism }\end{array}$ & Decoction taken orally. \\
\hline \multirow[t]{2}{*}{ Balsaminaceae } & \multirow[t]{2}{*}{ Impatiens balsamina L. } & \multirow[t]{2}{*}{ Keembung } & Leaves & Split nails & Pounded and applied topically. \\
\hline & & & Whole plants & Hypertension & Decoction taken orally. \\
\hline Bignoniaceae & Oroxylum indicum (L.) Kurz. & Pokok bekah & Barks & Family planning for women & Decoction taken orally. \\
\hline Blechnaceae & $\begin{array}{l}\text { Stenochlaena palustris (Burm.) } \\
\text { Bedd. }\end{array}$ & Pucuk miding & Young leaves & Fever & Juice applied topically. \\
\hline
\end{tabular}




\begin{tabular}{|c|c|c|c|c|c|}
\hline \multirow[t]{6}{*}{ Caricaceae } & \multirow[t]{6}{*}{ Carica papaya $\mathrm{L}$. } & \multirow[t]{6}{*}{ Betik } & Leaves & Amenorrhea & Blended with water and juice taken orally. \\
\hline & & & Young leaves & Fever & Infusion in brine taken orally. \\
\hline & & & Shoot, flowers & Hypertension & Scalded and eaten. \\
\hline & & & Sap of fruits & Pimples, skin blemish, cracks & Latex applied topically. \\
\hline & & & Ripe fruits & Constipation & Fruit eaten. \\
\hline & & & & Cough & Mixed with honey taken orally. \\
\hline Commelinaceae & $\begin{array}{l}\text { Amischotolype } \quad \text { mollissima } \\
\text { (Blume) Hassk. }\end{array}$ & Tebu tikus & Leaves & Hearing problem & Decoction used as drops. \\
\hline Connaraceae & Cnestis palala Griff. & Asam jawa bukit & Roots & Diabetes & Decoction taken orally. \\
\hline \multirow[t]{3}{*}{ Convolvulaceae } & \multirow[t]{3}{*}{ Ipomoea aquatica Fors. } & \multirow[t]{3}{*}{ Kangkung } & \multirow[t]{2}{*}{ Leaves } & Abscess & Pounded with salt and applied topically. \\
\hline & & & & Rough hair & Mashed in water and liquid used topically. \\
\hline & & & Whole plant & Food poisoning & Juice taken orally. \\
\hline \multirow[t]{3}{*}{ Crassulaceae } & \multirow[t]{3}{*}{ Bryophyllum pinnatum (L.) Pers. } & \multirow[t]{3}{*}{ Setawar/ Sedingin } & \multirow[t]{2}{*}{ Leaves } & Headache, abscess & Pounded and applied topically. \\
\hline & & & & Put in ear & Juice used as eardrops. \\
\hline & & & Leaves, roots & Skin itch & Pounded and applied topically. \\
\hline Dilleniaceae & $\begin{array}{l}\text { Tetracera indica (Hout. Ex Chris. } \\
\text { \& Panz.) Merr. }\end{array}$ & Mempelas & Roots & Hypertension, fever & Decoction taken orally. \\
\hline \multirow[t]{2}{*}{ Dioscoreacea } & Dioscorea orbiculata Hook.f. & Ubi takop & Tubers & Strengthen energy & Decoction taken orally. \\
\hline & Dioscorea alata L., & Huwi/ Ubi Papua & Tuber & $\begin{array}{l}\text { Tuberculosis, nephralgia, } \\
\text { splintage, haematemesis and } \\
\text { boils }\end{array}$ & $\begin{array}{l}\text { Dry it for } 4 \text { days. Pounded, soak with water and } \\
\text { Taken orally. }\end{array}$ \\
\hline \multirow[t]{9}{*}{ Euphorbiaceae } & \multirow[t]{2}{*}{ Manihot esculenta Crantz. } & \multirow[t]{2}{*}{ Ubi kayu } & Leaves & Cuts, bites, stings, abscess & Pounded and applied topically. \\
\hline & & & Tubers & Fever, headache, influenza & Pounded and applied topically. \\
\hline & $\begin{array}{l}\text { Chrozophora oblongifolia } \\
\text { (Delile) A.Juss. ex Spreng. }\end{array}$ & Kayu padang & Roots & Fitness & Decoction taken orally. \\
\hline & \multirow[t]{3}{*}{ Elateriospermum tapos } & \multirow[t]{3}{*}{ Perah } & \multirow[t]{2}{*}{ Latex } & Malaria & Rub it on the body. \\
\hline & & & & Glue & Blow pipe. \\
\hline & & & Fruit & Consume & Boiled, grilled or pickled. \\
\hline & Bridelia monoica (Lout.) Merr. & Kenidai & Leaves & Colic & Poultice applied topically. \\
\hline & \multirow[t]{2}{*}{ Croton tiglium L. } & \multirow[t]{2}{*}{ Changkian } & \multirow[t]{2}{*}{ Roots } & Oedema and abortion & Decoction taken orally. \\
\hline & & & & Purgative and fish poison & Dry it for 4 days. Pounded, soak with water. \\
\hline
\end{tabular}




\begin{tabular}{|c|c|c|c|c|c|}
\hline \multirow[t]{15}{*}{ Fabaceae } & \multirow[t]{3}{*}{ Senna tora $\mathrm{L}$. } & \multirow[t]{3}{*}{ Gelenggang seni } & Shoots & Constipation & Eaten raw. \\
\hline & & & Leaves & Skin diseases & Poultice applied. \\
\hline & & & Whole plants & Heartburn, post-partum & Decoction taken orally. \\
\hline & \multirow[t]{4}{*}{ Tamarindus indica $\mathrm{L}$. } & \multirow[t]{4}{*}{ Asam jawa } & \multirow[t]{3}{*}{ Fruits } & Fever, rough palm, swellings & Mixed in water and applied topically. \\
\hline & & & & Bites, stings & Split fruit applied topically. \\
\hline & & & & Sore throat & Juice taken orally. \\
\hline & & & Barks & Asthma, short of breath & Decoction taken orally. \\
\hline & \multirow{2}{*}{ Parkia speciosa Hassk. } & \multirow{2}{*}{ Petai } & Fruits & Diabetes & Eaten with the skin intact. \\
\hline & & & Roots & Hypertension & Decoction taken orally. \\
\hline & \multirow[t]{3}{*}{ Mimosa pudica $\mathrm{L}$. } & \multirow[t]{3}{*}{ Semalu } & \multirow[t]{2}{*}{ Whole plants } & Post-partum & Decoction taken orally. \\
\hline & & & & Athlete's foot pain & Pounded and applied topically. \\
\hline & & & Roots & Swelling & Pounded and applied topically. \\
\hline & Derris elliptica & Tuba & Barks, roots, stem & Poison & Dry it for 4 days. Pounded, soak with water. \\
\hline & \multirow{2}{*}{ Clitoria ternatea } & \multirow{2}{*}{ Bunga biru } & Leaves & Boils and coughs & Decoction taken orally. \\
\hline & & & Flowers & Conjunctivitis and bronchitis & Decoction taken orally. \\
\hline \multirow[t]{2}{*}{ Fagaceae } & Lithocarpus edulis & Mempening & Fruits & Post-partum & Eat it raw or cook. \\
\hline & Castanopsis inermis & Berangan & $\begin{array}{l}\text { Fruits, } \\
\text { seeds }\end{array}$ & Consume & Eat it raw or cook. \\
\hline Gramiceae & Lophatherum gracile Brongn. & $\begin{array}{l}\text { Rumput jarang/ rumput } \\
\text { kelurut }\end{array}$ & Roots & Stomach ache and chancres & Decoction taken orally. \\
\hline \multirow[t]{2}{*}{ Guttiferae } & \multirow[t]{2}{*}{ Garcinia cambogia } & \multirow[t]{2}{*}{ Gelugur } & \multirow[t]{2}{*}{ Fruits } & Consume & Slice and dry it fow few days-put it in cook. \\
\hline & & & & $\begin{array}{l}\text { Appetite control, fat loss, } \\
\text { digestion, worm, diarrhoea }\end{array}$ & Consume it raw or make it as oil. \\
\hline \multirow[t]{2}{*}{ Hypoxidaceae } & \multirow{2}{*}{$\begin{array}{l}\text { Molineria latifolia (Dryand. ex } \\
\text { W.T.Aiton) Herb. ex Kurz }\end{array}$} & \multirow{2}{*}{ Nyior lembe } & Leaves & Cuts, swellings & Poultice applied topically. \\
\hline & & & Rhizome & Coughs, no appetite & Eaten raw. \\
\hline \multirow[t]{5}{*}{ Lamiaceae } & \multirow{4}{*}{$\begin{array}{l}\text { Plectranthus scutellarioides (L.) } \\
\text { R. Br }\end{array}$} & \multirow[t]{4}{*}{ Ati-ati } & \multirow[t]{4}{*}{ Leaves } & Stomach ache & Leaves mixed with $\mathrm{CaCo} 3$ taken orally. \\
\hline & & & & Flatulence & Poultice mixed with $\mathrm{CaCo} 3$ applied topically. \\
\hline & & & & Cuts, sores, bites, stings & Poultice applied topically. \\
\hline & & & & Expel placenta, post-partum & Decoction with salt taken orally. \\
\hline & Hyptis brevipes Poit. & Setulang & Leaves & Swollen joints & Poultice mixed with $\mathrm{CaCo} 3$ applied topically. \\
\hline
\end{tabular}




\begin{tabular}{|c|c|c|c|c|c|}
\hline & \multirow{4}{*}{$\begin{array}{l}\text { Orthosiphon aristatus (Blume) } \\
\text { Miq. }\end{array}$} & \multirow[t]{4}{*}{ Misai kucing } & \multirow[t]{2}{*}{ Leaves } & \multirow{2}{*}{$\begin{array}{l}\text { Sore throat, difficult urination } \\
\text { Diabetes }\end{array}$} & \multirow{3}{*}{$\begin{array}{l}\text { Decoction taken orally. } \\
\text { Decoction with Andrographis paniculatus taken } \\
\text { orally. } \\
\text { Decoction taken orally. }\end{array}$} \\
\hline & & & & & \\
\hline & & & Leaves, flower & Headache & \\
\hline & & & Leaves, roots & Hypertension & Decoction taken orally. \\
\hline & Vitex longisepala King \& Gamble & Merian & Roots & Love potion & Decoction taken orally. \\
\hline \multirow[t]{7}{*}{ Lauraceae } & \multirow[t]{3}{*}{$\begin{array}{l}\text { Cananga odorata (Lamk.) Hk. f. } \\
\text { \& Thom }\end{array}$} & \multirow[t]{3}{*}{ Kenanga } & Leaves & Body odor & $\begin{array}{l}\text { Blend with lime, sugar and salt. Juice taken } \\
\text { orally. }\end{array}$ \\
\hline & & & Flowers & Scalp odor & Infusion in coconut oil applied topically. \\
\hline & & & Barks & Skin itch & Grated and applied topically. \\
\hline & Cinnamomum cuspidatum & Rempah gunung & Roots & Energy & Decoction taken orally. \\
\hline & Cinnamomum sp. & Kencing manis & Roots & Diabetes & Decoction taken orally. \\
\hline & Cinnamomum cinereum Gamble. & Tajalawang & Whole plants & Flatulence & Decoction taken orally. \\
\hline & Actinodaphene procera Nees & Huru/ Medang Kunyit & Barks & Tetanus & Decoction taken orally. \\
\hline Lecythidaceae & $\begin{array}{lll}\begin{array}{l}\text { Barringtonia } \\
\text { Gaertn. }\end{array} & \text { acutangula } & \text { (L.) } \\
\end{array}$ & Gajah beranak & Roots & Blood circulation & Decoction taken orally. \\
\hline \multirow[t]{2}{*}{ Leguminosae } & \multirow[t]{2}{*}{ Senna tora (L.) Roxb. } & \multirow[t]{2}{*}{ Ketepeng kecil } & Leaves & Purgative, cough and ringworms & Decoction taken orally. \\
\hline & & & Seeds & Anthelmintic & Decoction taken orally. \\
\hline Loganiacea & Strychnos pubescens C.B.Clarke & Tarik gajah & Leaves & Ticks' problem & Decoction taken orally. \\
\hline Loranthaceae & $\begin{array}{l}\text { Macrosolen } \\
\text { (Lour.) Tiegh. }\end{array}$ & Dedalu api & Stems & Diarrhoea & Decoction taken orally. \\
\hline \multirow[t]{4}{*}{ Lythraceae } & \multirow[t]{4}{*}{ Lawsonia inermis (L.) } & \multirow[t]{4}{*}{ Inai } & Leaves & $\begin{array}{l}\text { Dandruff, athlete's foot, weak } \\
\text { nails } \\
\text { Scar }\end{array}$ & $\begin{array}{l}\text { Pounded and applied topically. } \\
\text { Pounded with rice and applied topically. }\end{array}$ \\
\hline & & & & Kidney stones & Decoction taken orally. \\
\hline & & & Roots & Post-partum & Decoction taken orally. \\
\hline & & & Leaves, roots & Facial condition & Decoction taken orally. \\
\hline \multirow[t]{4}{*}{ Malvaceae } & Durio zibethinus Murray & Durian & Leaves & Influenza fever & $\begin{array}{l}\text { Mashed in water with leaves from several other } \\
\text { spices used as bath. }\end{array}$ \\
\hline & \multirow[t]{2}{*}{ Hibiscus rosa-sinensis $\mathrm{L}$. } & \multirow[t]{2}{*}{ Bunga raya putih } & Leaves & Fever, dry hair & Crushed in water and applied topically. \\
\hline & & & Roots & Cuts, sores & Grated and applied topically. \\
\hline & Urena lobata L. & Pulut-pulut & Roots & Post-partum & Decoction taken orally. \\
\hline Melastomataceae & $\begin{array}{l}\text { Melastoma malabathricum } \\
\text { L. }\end{array}$ & Senduduk & Fruits & Tongue pain & Placed on tongue pain. \\
\hline
\end{tabular}




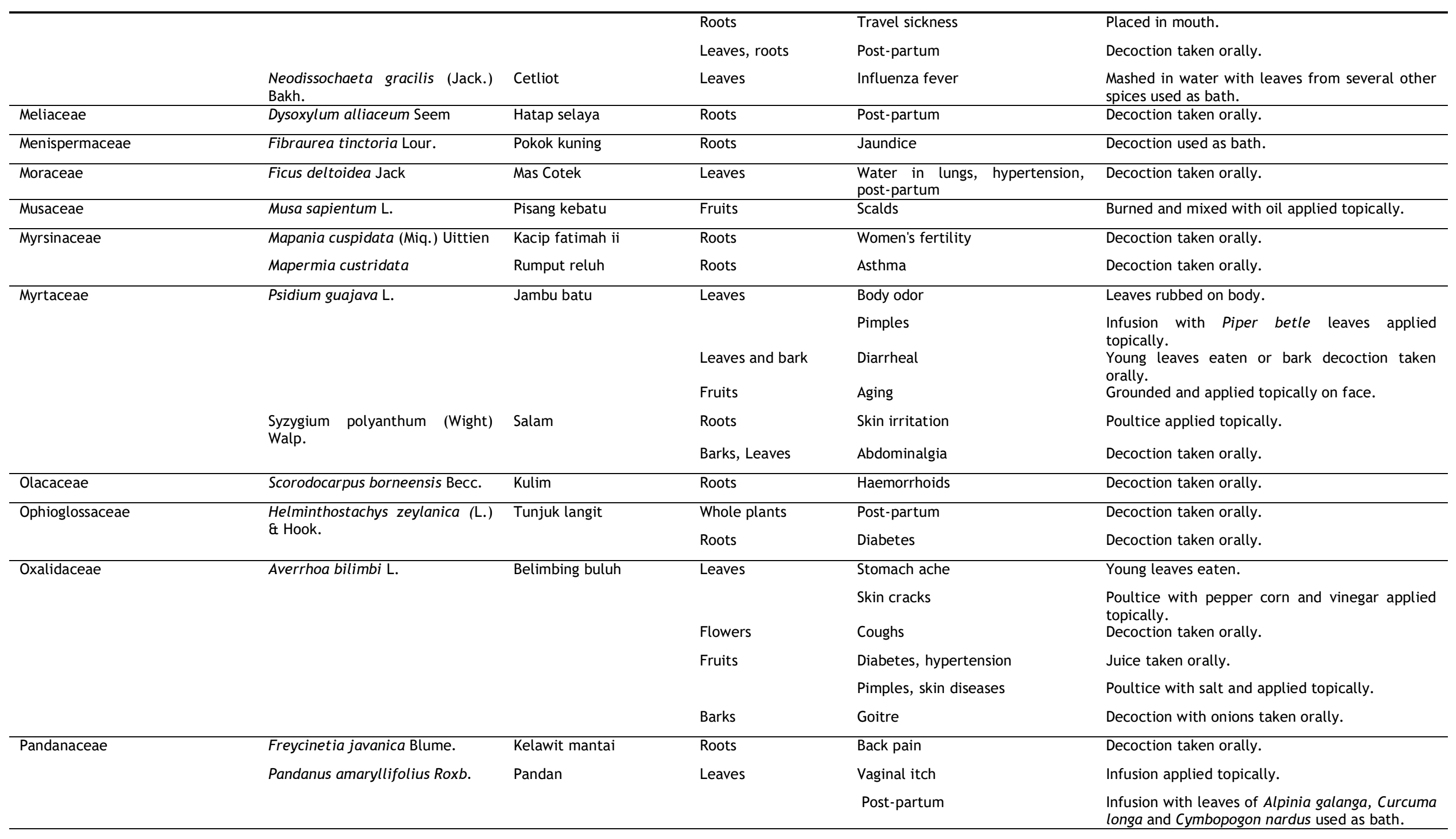




\begin{tabular}{|c|c|c|c|c|c|}
\hline \multirow[t]{5}{*}{ Phyllanthaceae } & Phyllanthus acidus (L.) Skeels. & Cermai & Leaves & Diabetes, hypertension, pimples & Decoction taken orally. \\
\hline & \multirow[t]{2}{*}{ Phyllanthus niruri L. } & \multirow[t]{2}{*}{ Dukung anak } & Whole plants & $\begin{array}{l}\text { Diabetes, hypertension, pain } \\
\text { during menses } \\
\text { Jaundice }\end{array}$ & $\begin{array}{l}\text { Decoction taken orally. } \\
\text { Decoction used as bath and also taken orally. }\end{array}$ \\
\hline & & & Leaves & Sores & Juice applied topically. \\
\hline & \multirow[t]{2}{*}{ Sauropus androgynus (L.) Merr } & \multirow[t]{2}{*}{ Cekok manis } & \multirow[t]{2}{*}{ Leaves } & Hair growth & Pounded with milk applied topically. \\
\hline & & & & Hypertension & Decoction taken orally. \\
\hline \multirow[t]{10}{*}{ Piperaceae } & \multirow[t]{7}{*}{ Piper betle L. } & \multirow[t]{7}{*}{ Sireh } & \multirow[t]{7}{*}{ Leaves } & Nosebleed & Rolled leaf inserted. \\
\hline & & & & $\begin{array}{l}\text { Toothache, sores, abscess, pain, } \\
\text { ache }\end{array}$ & Betel quid applied. \\
\hline & & & & Fever & Infusion applied topically. \\
\hline & & & & Vaginal itch & Decoction used as wash. \\
\hline & & & & Flatulence & Heated and applied topically. \\
\hline & & & & Poor eyesight & Decoction taken orally. \\
\hline & & & & Bad breath & Infusion used as gargle. \\
\hline & Piper nigrum L. & Lada hitam & Young fruits & $\begin{array}{l}\text { Diarrheal, headache, difficult } \\
\text { urination } \\
\text { Post-partum, loss appetite }\end{array}$ & $\begin{array}{l}\text { Decoction taken orally. } \\
\text { Pounded with anchovies and eaten with rice. }\end{array}$ \\
\hline & \multirow[t]{2}{*}{ Piper sarmentosum Roxb. } & \multirow[t]{2}{*}{ Kadok } & Leaves & Malarial fever & Decoction taken orally. \\
\hline & & & Roots & Diabetes, difficult urination & Decoction taken orally. \\
\hline \multirow[t]{9}{*}{ Poaceae } & Lophatherum gracile Brongn & Cekrek & Roots & Hypertension & Decoction taken orally. \\
\hline & \multirow[t]{4}{*}{ Cymbopogon citratus (DC) Stapf } & \multirow[t]{4}{*}{ Serai } & \multirow[t]{3}{*}{ Leaves } & Aches and pains & Pounded and juice applied topically. \\
\hline & & & & Hair loss, mosquito repellent & Decoction applied topically. \\
\hline & & & & Difficult urination & Decoction taken orally. \\
\hline & & & Whole plants & Fever & Decoction used as bath. \\
\hline & \multirow{3}{*}{$\begin{array}{l}\text { Cymbopogon winterianus Jowitt } \\
\text { ex Bor.. }\end{array}$} & \multirow[t]{3}{*}{ Serai wangi } & \multirow[t]{2}{*}{ Leaves } & Stomach ache & Decoction taken orally. \\
\hline & & & & Swellings & Poultice applied topically. \\
\hline & & & Whole plants & Painful menstruation & Decoction taken orally. \\
\hline & $\begin{array}{l}\text { Imperata cylindrica } \\
\text { Raeusch. \& P.Beauv. }\end{array}$ & Lalang & Rhizome & Fever & Infusion taken orally. \\
\hline
\end{tabular}




\begin{tabular}{|c|c|c|c|c|c|}
\hline \multirow[t]{5}{*}{ Polypodiaceae } & \multirow{5}{*}{$\begin{array}{llr}\begin{array}{l}\text { Pyrossia } \\
\text { M.G.Price }\end{array} & \text { piloselloides } & \text { (L.) } \\
& & \\
\text { Lignosus } & \text { rhinocerus } & \text { (Cooke) } \\
\text { Ryvarden } & & \end{array}$} & \multirow{5}{*}{$\begin{array}{l}\text { Duit-duit } \\
\text { Susu rimau }\end{array}$} & \multirow{5}{*}{$\begin{array}{l}\text { Leaves } \\
\text { Tubers }\end{array}$} & Headache & \multirow{3}{*}{$\begin{array}{l}\text { Pounded and applied topically. } \\
\text { Pounded with salt and rice, added warm water, } \\
\text { applied topically. } \\
\text { Burned and applied on chest. }\end{array}$} \\
\hline & & & & Skin itch & \\
\hline & & & & Asthma & \\
\hline & & & & Increase energy & Eaten raw \\
\hline & & & & $\begin{array}{l}\text { Breast cancer } \\
\text { Body aches }\end{array}$ & $\begin{array}{l}\text { Shredded and mixed with water applied } \\
\text { topically. } \\
\text { Decoction taken orally. }\end{array}$ \\
\hline Portulacaceae & Talinum fruticosum (L.) Juss. & Pokok duit RM5 & Leaves & Abscess, sores & $\begin{array}{l}\text { Pounded with Curcuma longa and rice, applied } \\
\text { topically. }\end{array}$ \\
\hline Primulaceae & Ardisia sp. & Kayu membuluh & Roots & Ulcer & Decoction taken orally. \\
\hline \multirow[t]{19}{*}{ Rubiaceae } & Ixora sp. & Pokok pengeras & Roots & Men mystic & Decoction taken orally. \\
\hline & Labisia pumila & Kacip fatimah i & Roots & $\begin{array}{l}\text { Women's fertility, Post-partum, } \\
\text { Increase the energy }\end{array}$ & Decoction taken orally. \\
\hline & Prismatomeris sp. & Haji samad & Roots & High blood pressure & Decoction taken orally. \\
\hline & Spermacoce articularis L. $f$ & Susu Kambing & Whole plants & Joint aches and pain & Decoction taken orally. \\
\hline & & & Roots & Muscle pains & Decoction taken orally. \\
\hline & Jasminum sambac (L.) Aiton. & Melor & Leaves & Fever & $\begin{array}{l}\text { Mixed with leaves of Canthium chartacea and } \\
\text { Gardenia jasminoides, crushed in water, liquid } \\
\text { applied topically and taken orally. }\end{array}$ \\
\hline & & & & Measles & $\begin{array}{l}\text { Mixed with leaves of Psidium guajava, Punica } \\
\text { granatum, Tamarindus indica, rhizome of } \\
\text { Curcuma longa and rice, pounded and applied } \\
\text { topically. }\end{array}$ \\
\hline & & & Flower buds & Pimples, skin infections & Pounded and applied topically. \\
\hline & & & Roots & $\begin{array}{l}\text { Leucorrhoea, } \\
\text { menstruation }\end{array}$ & Decoction taken orally. \\
\hline & Mitragyna speciosa (Korth.) Havil & Ketum & Leaves & Headache & Pounded with salt applied on forehead. \\
\hline & Morinda corneri K. M. Wong & Mengkudu hutan & Leaves, fruits & Post-partum & Decoction taken orally. \\
\hline & & & Fruits & Hypertension & Flesh eaten. \\
\hline & & & Roots & Difficult urination & Decoction taken orally. \\
\hline & $\begin{array}{l}\text { Timonius wallichianus (Korth.) } \\
\text { Val. }\end{array}$ & Patah bawah tangga & Roots & Low sexual energy for man & Decoction with another herb taken orally. \\
\hline & Myrmecodia pendans & Sarang semut & Bulbs & $\begin{array}{l}\text { Cancer, antibiotic, antioxidant, } \\
\text { fever, gout, diarrhoea }\end{array}$ & $\begin{array}{l}\text { Slice, wash and Decoction. Make it as tea and } \\
\text { taken orally. }\end{array}$ \\
\hline & Paederia foetida L., & Akar sekentut & Roots & Fever and stomach ache & Decoction taken orally. \\
\hline & & & Leaves & $\begin{array}{l}\text { colds, herpes, conjunctivitis, } \\
\text { palsy, dysentery and } \\
\text { rheumatism, }\end{array}$ & Decoction taken orally. \\
\hline & Canthium borridum Blume & Bulangan & Barks & Dysentery & Decoction taken orally. \\
\hline & & & Leaves & Conjunctivitis & Decoction taken orally. \\
\hline
\end{tabular}




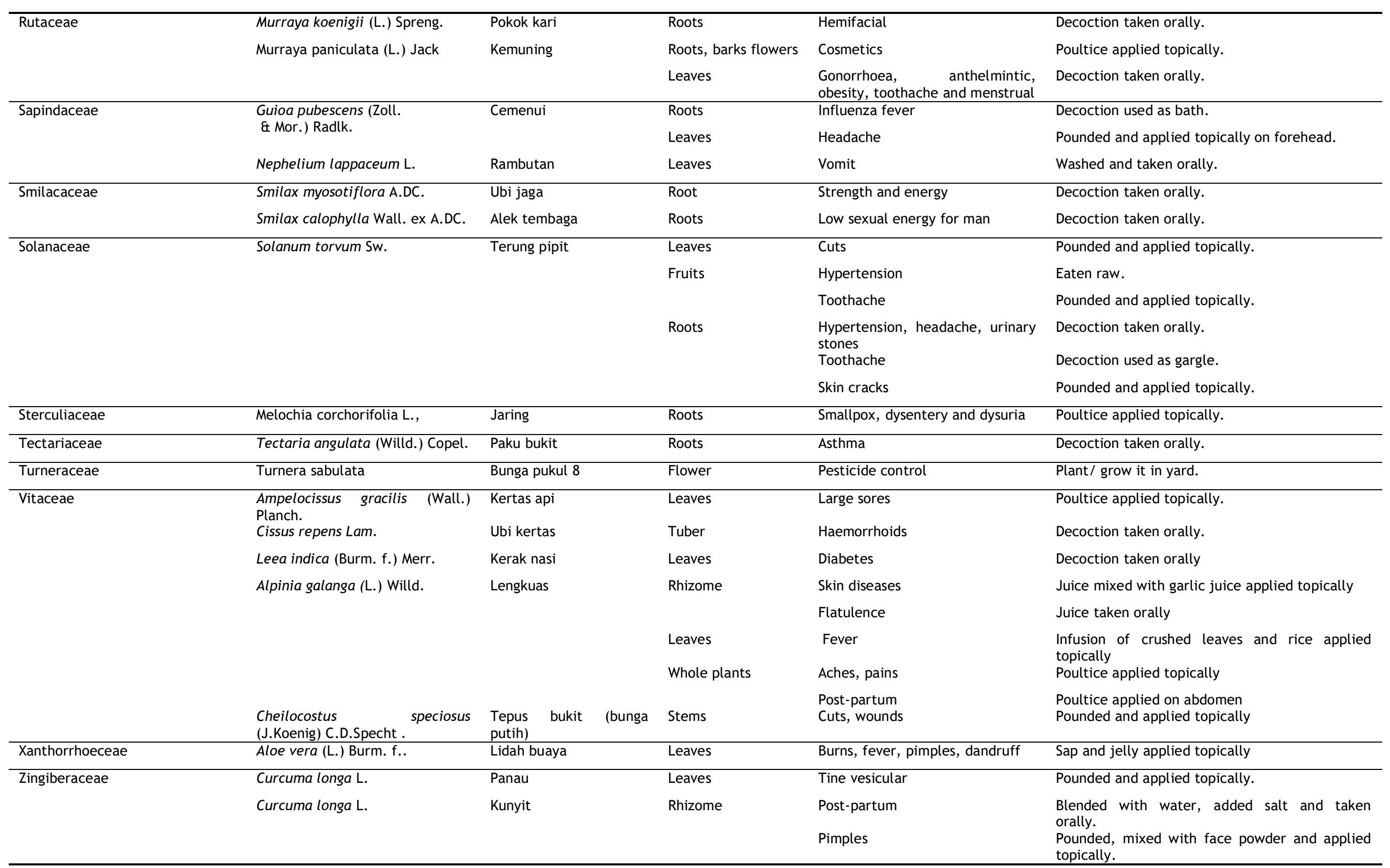


Sores, athlete's foot

\section{Abrasions}

Curcuma viridiflora Roxb.

Kunyit emas

Curcuma zanthorrhiza Roxb.

\section{Temulawak}

Etlingera elatior (Jack) R.M.Sm.

Kantan

Hedychium longicornutum Griff

ex Baker

Zingiber officinale Roscoe.
Ramu akar cacing

Halia
Young rhizome

Old rhizome

Facial dermatitis

Difficulty breathing

Aging

Rhizome

Roots

Leaves

Fruits

Roots

Leaves

Rhizome

Ageing

Cuts, wounds

Body aches

Earache

Worms

Sprain

Flatulence
Poultice with coconut oil, applied topically.

Slices applied topically.

Eaten raw.

Juice applied topically on the chest.

Pounded with Centella asiatica, juice taken orally.

Hemafecia, water in lungs

Pain during menses

Bites, stings, headache

Leucorrhoea

Post-partum

Weak teeth
Juice taken orally.

Decoction taken orally.

Decoction used to wash and applied topically.

Decoction used as bath.

Decoction used as are drops.

Decoction used as bath.

Pounded and applied topically.

Decoction taken orally.

Juice taken orally.

Pounded and applied topically.

Compounded decoction with roots of Capsicum frutescens, Ricinus communis and cumin seeds taken orally.

Pounded with pepper, turmeric, eaten with rice.

Pounded with salt, juice used as gargle. 